\title{
Contested Belonging: Temporary Protection in Australia
}

\author{
Louise Humpage and Greg Marston
}

\begin{abstract}
This paper utilizes an analytical distinction between three modes of social belonging to explain the ambiguous resettlement experiences of refugees granted a temporary protection visa (TPV) in Australia. Findings from two qualitative studies indicate that the dominance of a public discourse that depicts asylum seekers as "illegals" inhibits their sense of belonging at the national level. Yet belonging has been facilitated locally through relational networks within communities and the establishment of associations based on cultural or legal categories. Importantly, these successes have provided a basis from which to contest the continued lack of recognition faced by TPV refugees within a nationalistic public discourse.
\end{abstract}

\section{Résumé}

Cet article fait appel à une différence analytique entre trois modes d'appartenance sociale pour expliquer l'expérience ambiguë de la réinstallation vécue par les réfugiés qui obtiennent un TPV ("visa de protection temporaire») en Australie. Les conclusions de deux études qualitatives indiquent que la dominance d'un discours publique représentant les demandeurs d'asile comme des "clandestins", bloque leur sens d'appartenance au niveau national. Au niveau local cependant, l'appartenance a été facilitée à travers des réseaux de relations à l'intérieur des communautés et l'établissement d'associations basées sur les catégories culturelles ou légales. Ce qui importe encore plus c'est que ces succès ont fourni une base à partir de laquelle il est maintenant possible de contester le manque de reconnaissance confrontant les réfugiés TPV dans l'environnement crée par un discours publique nationaliste.

\section{Introduction}

The introduction of the temporary protection visa (TPV) in Australia has had important repercussions for the resettlement experiences and citizenship status of refugees. Having already spent considerable time in transit, refugees issued a TPV are forced into a continued state of limbo by the policy of mandatory detention. Once finally released into the Australian community, their visa status provides few settlement services and even fewer rights. Despite these hurdles, many such refugees have developed a sense of belonging at the local level and, according to the goals of many refugee resettlement policies, might be considered "integrated." This sense of belonging is, however, continually contested at the level of public discourse where political rhetoric justifies the temporary protection offered to such refugees by representing them as "illegals" or "queue jumpers." In making sense of this ambiguous outcome, the paper builds on growing awareness that we need to understand social integration and belonging as far more complex and multi-faceted than resettlement policies and programs typically acknowledge. This is particularly the case for "unauthorized" asylum seekers who are subject to greater stigmatization than refugees accepted through conventional offshore programs.

To this end, the first section of the paper draws upon Calhoun's distinction between relational networks, cultural or legal categories, and discursive publics as modes of social belonging that represent citizenship. ${ }^{1}$ Doing so allows us to deconstruct traditional understandings of belonging and integration in a way that provides an explanation for the ambiguous resettlement experiences of refugees granted a TPV and living in the state of Victoria, Australia. The second section of the paper maps out the political context in which temporary protection policies were introduced in Australia, as well as the specific entitlements and restrictions that accompany the TPV. This draws attention to a dominant public discourse, which contests the ability and 
right of refugees on TPVs to belong. The third and final section of the paper explores the experiences of refugees on TPVs, as documented in two qualitative research studies undertaken by the authors. In this discussion, emphasis is placed on both the continuing effects such a negative public discourse has had upon refugees on TPVs and the successes achieved by a Melbourne community-based organization in facilitating a sense of belonging amongst refugees on TPVs at the local level. Consequently, this sense of belonging and partial security has provided the support needed to challenge the continued lack of recognition confronting refugees due to dominance of a public discourse that demonizes and devalues them.

\section{Extending the Debate around Integration and Belonging}

The notion of refugee integration is not easily defined, although this term usually refers to a long-term process that results in refugees being able to participate in all aspects of the host society where they now live, without having to give up their own cultural identity. ${ }^{2}$ The refugee studies literature demonstrates that the integration process is one complicated by numerous variables. A distinction is commonly made, for example, between economic and cultural or social aspects of integration. Typical refugee programs, not surprisingly, tend to concentrate their often meagre resources on the former because the functional issues of housing, employment, and education are regarded as the fastest means for integrating refugees within the community. ${ }^{3}$

There is, however, widespread recognition within the literature that successful resettlement also requires attention to be paid to the cultural and social needs of refugees, which are multiple and complex. Berry, Kim, and Boski for example, have identified that cultural adaptation involves physical, biological, cultural, and social change within refugee individuals, ${ }^{4}$ while Liev has developed an integrated model indicating that refugees adapting to a host society experience stress at the individual, familial, group, or or ganizational levels. ${ }^{5}$ Nevertheless, Bihi highlights that many models of refugee integration focus predominantly on psychological interpretations of displacement. ${ }^{6}$ This can lead to the misunderstanding that refugees are unable to adjust because of previous suffering, when policy and program failure may be a major contributor to their ill- adjustment.

Korac's comparative research in the Netherlands and Italy provides compelling evidence that the official resettlement policies adopted by different countries have a significant impact on integration, not only in relation to the functional concerns of housing, employment, and education, but also in regard to the social participation of refugees in wider society, which influences their sense of identity, belonging, recognition, and self-respect. ${ }^{7}$ She documents how refugees in the Netherlands were unable to overcome a sense of detachment from their host society that developed during prolonged stays in asylum centres, despite receiving relatively high degrees of formal assistance with employment and housing. They were thus largely unsuccessful in establishing closer ties with Dutch citizens. In contrast, refugees in Italy received minimal assistance through self-help systems established within refugee and migrant networks. As a result, they became not only more self-sufficient, but also better integrated into Italian society. Although experiencing considerable difficulties with housing and work in their initial phase of resettlement, in addition to remaining clustered in predominantly low-paying jobs, most of the refugees in Italy felt a greater sense of belonging than those living in the Netherlands.

These ambivalent results led Korac to conclude that spontaneous and individualized encounters between refugees and host society members help avoid negative, hierarchical perceptions of the "other" and encourage a mutual process of learning and shifting from which both groups can gain. ${ }^{8}$ Yet, refugee assistance programs often treat refugees as having "immature social identities" in need of cultural and social re-education. This has resulted in language acquisition and cultural adaptation being used as the key indicators when assessing levels of integration. Korac argues that strategies for building the kind of "bridging social capital" which provides refugees with a sense of rootedness and wider belonging are more useful than those that regard integration as one-way assisted process. This is because the latter treats refugees as policy objects, rather than as a vital resource in the integration process.

These findings go some way to explaining the experiences of refugees on TPVs living in Australia. In exploring the meaning of this ambivalent space, we have found Calhoun's discussion of the different modes of social belonging that represent citizenship useful in extending the debate around issues of social or societal integration. ${ }^{9}$ Calhoun argues that there has been a lack of attention paid to distinctions between three different modes of social belonging. First, belonging exists as the level of "communities," which consist of relatively small groups that are primarily constituted through informal, directly interpersonal relationships rather than formal political-legal institutions. "Categories," on the other hand, are commonly comprised of large numbers of people who are not knit by the dense interpersonal relationships that constitute communities, but develop a sense of belonging around their shared culture or legal status. Calhoun suggests that the rhetorics of culture and community are problematic ones by which to grasp political rights. He thus argues that we need to recog- 
nize "publics" as a third distinctive mode of social belonging. These are quasi-groups constituted by mutual engagement in discourse aimed at determining the nature of social institutions, including nation-states. Here belonging is not based on dense webs of common understandings or shared, taken-for-granted social relations but, as Calhoun has noted elsewhere, on "socially sustained discourses about who it is possible or appropriate or valuable to be."10 This can lead to problems of recognition for those who do not match dominant discourses regarding valued social identities.

Calhoun's intention in making these distinctions is to highlight theoretical weaknesses in current approaches to citizenship, particularly the way in which discourses of political community are deeply shaped by nationalism. He argues that this has resulted in our using terms like "community" as though there is no problem in making them refer to local, face-to-face networks at the same time as whole nations conceived of categories of culturally similar persons. Yet:

Membership in a society is an issue of social solidarity and cultural identity as well as legally constructed state citizenship. This is all the more important to recognize in an era shaped by new cultural diversities and new challenges to the abilities of states to maintain sharp and socially effective borders. ${ }^{11}$

We believe that the distinction between belonging in terms of relational networks, cultural or legal categories, and discursive publics is extremely valuable for understanding the rather ambiguous resettlement process experienced by refugees on TPVs in Australia. In indicating both the catalysts for, and obstacles to, their sense of belonging, we demonstrate the utility of making analytical distinctions between modes of social belonging when planning, implementing, and assessing policy and programs aimed at enhancing refugee integration. In turn, we hope to inform what Castles calls a sociology of forced migration that understands "exile, displacement and belonging" as a part of social process in which human agency and social networks play a major role, if in the context of global social transformation. ${ }^{12}$

\section{Public Discourses around Temporary Protection}

Public discourse is an area of debate dependent on the competing articulation of differences of ideas, opinions, and identities. In this way, it is also the site of explicit and implicit attempts at persuasion. ${ }^{13}$ Castles notes that asylum and other forms of forced migration have become major themes of political debate in many countries as the numbers of people displaced each year has grown through the 1990s. ${ }^{14}$ It is beyond the scope of this paper to consider the economic uncertainty and security concerns that have produced this result, but it is clear that refugees and asylum seekers have been regarded as physically embodying an external threat to jobs, living standards, welfare, and the dominance of the nation-state as the focus of social belonging. The issue of forced migration has, as a consequence, become increasingly marked by heated public debates and competition between the political parties as to who is the toughest on "illegals."

Given the enormous political and financial resources that can be used to support them, the highly politicized discourses promoted by governments frequently dominate the public domain. This has certainly been the case in Australia, where political rhetoric around the issue of asylum and temporary protection has attempted to influence public opinion regarding the Australian Government's immigration and border protection policies by playing on existing public fears and insecurities. Australia has historically enjoyed a positive international reputation for its interpretation of the 1951 United Nations Convention relating to the Status of Refugees and 1967 Protocol. Certainly, an estimated 650,000 refugees have been accepted as permanent residents since 1945 and 12,000 places are currently set aside each year for the humanitarian component of its permanent immigration program. ${ }^{15}$ Yet, Australia has long demonstrated a preoccupation with controlling its borders to prevent entry of others. The most obvious example is the "White Australia" sentiment that dominated policy from 1901 to the early 1970s. ${ }^{16}$

Although such explicitly racist policy has officially been abandoned, Australia continues to be a nation that demonstrates hostility towards its immigrant foundations. The most recent manifestations of such hostility are the controversial policies on mandatory detention, border protection, and temporary protection. These have established a distinction between "good" refugees and "bad" refugees. The former are selected overseas, usually after referral from the United Nations High Commissioner for Refugees, and enter Australia with a visa that entitles them to permanent residency (and to apply for citizenship after the prescribed waiting period). "Bad" refugees, on the other hand, are asylum seekers arriving in Australia by boat without "authorization"; that is, a visa and/or a valid passport.

This distinction was established in 1989 when the Keating Labor government began automatically detaining unauthorized arrivals, a practice formalized by the Migration Amendment Act 1992. ${ }^{17}$ However, the temporary protection visa introduced by the Howard Liberal-National government in October 1999 further entrenched this division between "good" and "bad" refugees. It also marked a shift 
towards dealing with asylum seekers in terms of border protection policy, rather than human rights protection under the 1951 Convention and 1967 Protocol. Unauthorized arrivals found to be refugees are now granted TPVs for a period of three years (in some cases, five years) instead of the permanent protection visas (PPVs) formerly offered.

Prior to September 2001, refugees with TPVs due to expire could apply for a PPV, which would grant them Australian residency status. Since that date, unauthorized arrivals assessed as meeting the refugee classification are no longer able to seek a PPV if, since leaving their home country, they resided for at least seven days in a country where they could have sought and obtained effective protection. According to present policy, refugees granted TPVs since 2001 may consequently have the right to seek another TPV, but will never be able to seek permanent protection in Australia. ${ }^{18}$

Australia's TPV regime was founded on real concerns about the increasing misuse of Australia's onshore protection arrangements by organized people smugglers and owes its continuing existence to the political belief that it discourages the illegal entry of asylum seekers into Australia. ${ }^{19}$ Its introduction coincided with and has manipulated an existing public discourse representing asylum seekers as queue jumpers who offend the Australian sense of "fair play." With the weight of the Australian Government behind it, this discourse has overwhelmed counter-stories indicating that the selection of refugees for resettlement is more like a lottery than an orderly queue process ${ }^{20}$ and that making a formal application is neither practical nor possible for most refugees. ${ }^{21}$ This was certainly the case for most of the 8,860 refugees who had been granted a TPV in Australia by October 2003. For instance, 3,658 were from Afghanistan and 4,254 from Iraq, both troubled nations where formal refugee applications were impossible to make. ${ }^{22}$

Importantly, the majority of refugees on TPVs are also single males or married men who left their families at home or in another country and are practicing Muslims. These ethnic, gender, and religious characteristics have worked against refugees on TPVs as together they have been portrayed as representing a "threat" to Australia's social cohesion. Marr and Wilkinson conclude that the Australian Government's border protection policy combines a crude racism with genuine concern for the security of the country that is best described as "race wrapped in the flag." ${ }^{23}$ This racism builds on existing understandings of "Australian Muslims" and "mainstream Australians," which Nebhan suggests are positioned along different sides of an imaginary border that separates two seemingly totalized "cultures." ${ }^{24}$ The events of 11 September 2001 did nothing to either discourage such beliefs or improve the image of refugees, who have been branded as a sinister transnational threat to national security even though none of the September 11 terrorists were actually refugees or asylum seekers. ${ }^{25}$

Indeed, this attack on the United States appeared to support the Australian Government's depiction of refugees seeking asylum as unable to leave conflict at home behind, even when opposition to what the Prime Minister, John Howard, calls "evil and terrorism" was a key factor in their departure. ${ }^{26}$ The Minister for Defence, Peter Reith, explicitly suggested that terrorists might be lurking amongst "boat people." ${ }^{27}$ Meanwhile, the Minister for Immigration, Phillip Ruddock, characterized asylum seekers arriving by boat as "those who have the money, those who are prepared to break the law, those who are prepared to deal with people smugglers and criminals." ${ }^{28}$ The bogus "children overboard" incident ${ }^{29}$ nonetheless provides the most striking demonstration of the way in which "bad" refugees have been represented as lacking the required (yet ill-defined) values Howard's government wishes to muster and affirm. Howard, in referring to the alleged child-throwers, stated: "I don't want people like that in Australia. Genuine refugees don't do that ... They hang onto their children." ${ }^{30}$

Political concern about national security and integrity has fuelled a public discourse which casts refugees as a "deviant" problem that should be expelled from Australia's national borders. This category of "refugee" is constructed as being incapable of possessing the qualities a person must have in order to be considered a "real" citizen. ${ }^{31}$ This has had repercussions not only for the recognition of asylum seekers as refugees but also for the resettlement of those deemed to meet these criteria. While refugees granted a PPV are able to begin their resettlement process immediately and have access to a variety of resettlement programs and services, those arriving without official documents are sent to one of several detention centres around the country. Mandatory detention may have helped alleviate growing social and political pressures caused by Australia's fear of being "swamped" by newcomers. ${ }^{32}$ But there is evidence to suggest that the poor conditions and prison-like nature of detention in Australia have detrimental effects upon the physical, social, and psychological health of refugees on TPVs. ${ }^{33}$ In addition, although many refugees on TPVs have been in Australia for up to five years, their resettlement has been effectively delayed from anywhere between a few months to a few years.

After being released from detention, refugees on TPVs continue to be treated as "second-class citizens" in terms of access to settlement services. The accompanying table provides a snapshot of the different entitlements that refugees on TPVs are able to access in comparison to refugees granted a permanent protection visa. ${ }^{34}$ 
Entitlements Associated with Temporary Compared to Permanent Protection Visas

\begin{tabular}{|c|c|c|}
\hline Entitlement & $\begin{array}{l}\text { Permanent Protection Visa } \\
\text { Arrived onshore without a visa } \\
\text { \& } \% \text { or valid passport }\end{array}$ & $\begin{array}{l}\text { Temporary Protection Visa } \\
\text { Selected through offshore refugee program }\end{array}$ \\
\hline Residency status & $\begin{array}{l}\text { Permanent, right to apply for Australian } \\
\text { citizenship. }\end{array}$ & $\begin{array}{l}\text { Temporary (usually } 3 \text { years), no right to permanent protection } \\
\text { (and thus Australian citizenship) if spent } 7 \text { days or more in a } \\
\text { country where effective protection could have been sought and } \\
\text { obtained (since Sept 2001). }\end{array}$ \\
\hline Travel & $\begin{array}{l}\text { Same ability to leave the country and } \\
\text { return as other permanent residents. }\end{array}$ & Travel, even if permitted, voids any protection submission. \\
\hline Family Reunion & $\begin{array}{l}\text { Able to bring immediate family } \\
\text { members. }\end{array}$ & No family reunion rights, even for spouse and children. \\
\hline Settlement Support & $\begin{array}{l}\text { Access to full federally funded settlement } \\
\text { services, including Migrant Resource } \\
\text { Centres, interpreter service and } \\
\text { integration assistance. }\end{array}$ & $\begin{array}{l}\text { Not eligible for most federally funded services, except for } \\
\text { health screening and referral. }\end{array}$ \\
\hline Housing & $\begin{array}{l}\text { Assistance with public housing included } \\
\text { within settlement services. }\end{array}$ & $\begin{array}{l}\text { Not entitled to on-arrival accommodation. Limited access to } \\
\text { public housing. }\end{array}$ \\
\hline Work rights & Permission to work. & Permission to work but job search assistance severely restricted. \\
\hline Income Support & $\begin{array}{l}\text { Immediate access to the full range of } \\
\text { federal social security benefits. }\end{array}$ & Access only to Special Benefit for which criteria apply. \\
\hline Education & $\begin{array}{l}\text { Same access to education as other } \\
\text { permanent residents. }\end{array}$ & $\begin{array}{l}\text { Access to primary, secondary and vocational education subject } \\
\text { to state policy (access granted in Victoria). Effective exclusion } \\
\text { from tertiary study due to imposition of international student } \\
\text { fees. }\end{array}$ \\
\hline English classes & $\begin{array}{l}\text { Eligible for } 510 \text { hours of federally funded } \\
\text { English language training. }\end{array}$ & $\begin{array}{l}\text { Not eligible for federally funded English language programs or } \\
\text { translating and interpreting services, although since Jan } 2003 \\
\text { Special Benefit recipients have some access to basic Language, } \\
\text { Literacy and Numeracy Programs. }\end{array}$ \\
\hline Medical Benefits & $\begin{array}{l}\text { Same eligibility for Medicare and Health } \\
\text { Care Card as other permanent residents. }\end{array}$ & Eligible for Medicare and Health Care Cards. \\
\hline
\end{tabular}

The above table is adapted from Brotherhood of St Lawrence, "Seeking Asylum: Living with Fear, Uncertainty and Exclusion," Changing Pressures Bulletin 11 (November 2002)

There are literally thousands of such "temporary citizens" whose lives are curtailed by their limited access to basic rights and services, as well as the more fundamental personal freedoms detailed above. The next section suggests, however, that many refugees on TPVs are beginning to integrate and belong, despite the continuing uncertainty, shame, and lack of control that result from the negative discursive representations that dominate the public arena.

\section{Beginning to Belong: Refugees on Temporary Protection Visas in Victoria}

An analytical distinction between modes of belonging at the levels of community, cultural or legal categories, and dis- cursive publics has been established to draw attention to the complexity of social integration. Findings from two qualitative research studies offer evidence that belonging consists of sets of overlapping and interconnected processes that take place differently in various sub-sectors and spheres of receiving societies and have various outcomes. ${ }^{35}$ First, an action research project conducted in 2002-2003 highlights the continuing and negative impact that the dominant public discourse surrounding the TPV regime has had on refugees. ${ }^{36}$ Second, a further 2003 interview study highlights the way in which an innovative community organization has assisted refugees on TPVs to develop a sense of belonging at the community and category levels. ${ }^{37}$ 
This in turn has provided a basis for such refugees to contest the public discourse that both devalues and demonizes them.

\section{Devalued and Demonized: The Effects of a Public Discourse}

Without a doubt, the highly politicized public discourse dominating debate around the TPV regime has negatively impacted upon the resettlement of refugees. The material hardships faced by refugees on TPVs were an important theme in the first research study, which involved in-depth interviews with fifty-one refugees on TPVs and fifteen service providers living in Melbourne or regional centres of Victoria. The majority of the TPV refugees survived on very limited incomes, lived in insecure housing, had ongoing health problems, and were restricted in their access to educational opportunities. These issues, although common to other refugees, were discovered to be profoundly connected with their legal and rhetorical positioning in the dominant public discourse.

Labour market participation, for example, was inhibited by the temporary nature of the protection offered by the TPV. Refugees told of direct discrimination by employers, who frequently mistook the TPV to be a form of tourist visa (which does not allow employment) or were wary of employing someone granted only temporary status. A participant in a regional group interview proclaimed: "I can't get a job around here. They look at my visa and they say no straightaway. The boss says no!" Others spoke of the indirect effects of holding a TPV. These included the inability to gain proficiency in English (due to federally funded English-as-a-second-language (ESL) providers being restricted from enrolling refugees on TPVs) and to receive assistance in gaining domestic work experience or to have their qualifications recognized (due to limited access to Job Network services).

These obstacles, established by federal government policy, disguised the desire of many TPV holders to participate in and contribute to society to a degree far greater than their limited visa status allows. For example, an Iraqi expressed his wish: "Just to be able to do something, to work, to contribute to this society, to feel that I'm doing something and not on Special Benefit." Yet, the poverty traps and work disincentives associated with the Special Benefit, a discretionary payment for those in severe financial need due to circumstances outside their control, resulted in reported Centrelink debts for about a quarter of the fifty-one refugees interviewed. This raises fundamental policy questions about whether the Special Benefit is the right payment for people who are living in Australia for at least three years and who are both keen to work and highly motivated to gain greater financial independence.
Given the many practical obstacles faced by refugees on TPVs, it is telling that refugee participants considered their most significant barrier to resettlement to be the ongoing psychological uncertainty and distress caused by the TPV and mandatory detention regimes. The participants indicated that the limited freedom and sense of isolation associated with the legal conditions of their visa far outweighed material concerns about access to resettlement services. A female refugee noted in a focus group:

But all of these things result from the very important matter, which is really affecting the situation of TPV holders, the psychology of the situation, resulting from the temporary living situation. Okay, yeah, all of these other things ... the services that we are not eligible for, produce a very bad environment, a psychological environment. So this is the thing that we have to focus on, which is why we are always talking about the temporary protection visa.

All of the refugees interviewed made a direct connection between their temporary visa status and their feelings of stress, anxiety, hopelessness, and uncertainty: "I just think about it and I feel depressed, you know, a lot of pressure, thinking about everything." The deep uncertainty associated with the TPV severely restricts the capacity of refugees to recover from a traumatic past, as well as to dream and hope for a better future. As a result, many described the TPV as a "secondary form of punishment," similar to living like "an island cut off from the mainland." While the emotional, spiritual, and mental resilience among the refugee research participants was inspiring, the reality of living with a TPV on a day-to-day basis represented the final straw. They described the experience of shrinking hope:

Once we got to Australia we thought we would be safe and protected ... and then we came to this ... and then we got this temporary protection visa, we thought we were slowly dying again because we started a new form of suffering.

In particular, they could not make sense of how they had been recognized as genuine refugees, yet still had to live with such uncertainty, as an Iraqi participant suggested:

First of all we are discriminated as a group of people who are not equal to the others [refugees granted PPVs], and at the same time, we have the same condition as the others - they got refugee status and a whole right.

This situation caused some to hold deep fears about forcibly being deported to the country they have fled: "Three years, and what's next, deportation, back to detention centres, or back to our country to the serious death or jail." 
Not surprisingly, the pivotal hope for research participants centred on attaining permanent residency, which they believed would give them the psychological security and material stability needed to plan for a future free from political persecution, torture, and trauma. They indicated that permanent protection would enable refugees on TPVs to regain a sense of control over their own lives, defined in terms of autonomy and agency in regard to securing residency, family reunion, employment, health, education, and participation in cultural and public activities. Yet, the future of the refugees as permanent residents and everything that flows from this state of ontological and legal security is currently subject to an external decision of a governmental authority. The powerlessness felt by TPV holders as a result has been exacerbated by the way in which expiring TPVs have been replaced by an automatically issued special threeyear Class XC visa until immigration officials redetermine the refugee status of each visa holder. More than 90 per cent have applied for further protection visas, but so far only 350 decisions have been made and 342 were refused. ${ }^{38} \mathrm{~A}$ "freeze" has been placed on Iraqi applications, presumably until the situation in their homeland improves enough for them to be returned without an international outcry.

The devalued citizenship status offered to refugees on TPVs, which has led to continuing discrimination, uncertainty, and powerlessness, was a humiliating experience for many participants. One young Iranian said: "I feel I'm not equal or normal person like others here, unusual in this community. Sometimes I try to hide my identity as a TPV because I feel ashamed." But, importantly, many recognized that they were simply pawns in a political game. For example, one refugee highlighted the way in which he believed refugees had been demonized to deny them any claim for justice:

The Minister of Immigration, whenever he comes to the media, he created bad image or serious type of propaganda against us, that's all he did for us. He never mentioned anything about our suffering and the way that the Iraqi regime, how bad they've been treating the Iraqi people, and our stories, why we are here, individual or in general ... they forgot everything about that.

The next section demonstrates that, alongside assistance provided by innovative community organizations and sympathetic individuals, this political awareness has enabled refugees on TPVs to contest the official public discourse that devalues and demonizes them. Yes, the TPV regime, which has had such a significant impact on the hearts and minds of thousands of refugees in Australia, illustrates the way in which the construction of social identities shapes people's capacities for mobility. ${ }^{39}$ To focus on these negative experiences alone, however, would tell only part of the story regarding the integration of refugees on TPVs in Australian society.

\section{Involved and Empowered: The Effects of an Innovative Refugee Program}

According to Calhoun's analysis, two other modes of social belonging sit beside that which develops at the level of discursive publics. We concentrate first on belonging at the level of communities, which Calhoun defines in terms of informal, directly interpersonal relationships, because these have had an enormous effect on the integration process of refugees on TPVs. The refugee participants who spoke of uncertainty, shame, and powerlessness in the last section also highlighted how they overcame some of the material barriers to their resettlement through access to a well-informed community advocate and supportive informal networks. For instance, many refugee participants told how they managed to overcome difficulties obtaining rental accommodation only with the assistance of an advocate:

So I'd been rejected twenty times by agents and that was very hard for me. I had no rental history. I was thinking of going back to Adelaide because I couldn't stay any longer with my friend and his children. Then someone from a local migrant group came with me to the agent and she talked to them, and he was a Muslim man, so didn't have the same discrimination as the others. And that's how I got my unit, but it's not in very good condition.

Many organizations assisting refugees provide the direct advocacy highlighted here themselves or arrange a community "sponsor" to provide advice and practical help in the first few weeks or months of refugee resettlement. Some of these formal relationships turn into friendships. But the artificial and temporary manner in which refugees and sponsors are matched, along with the pressing needs of newly arrived refugees, often result in such friendships being based largely around practical issues, such as finding and furnishing a house or providing an introduction to the health and welfare system.

As a consequence, a community-based Neighbourhood House and adult learning centre in Melbourne called the Fitzroy Learning Network has attempted to establish more "natural" settings for friendships to develop, in addition to the considerable social welfare and material assistance provided by its paid staff. The Network offers a range of innovative social activities where past and present students, volunteers, staff, and "friends" of the Network can mingle informally. The most important of these are: weekly community lunches; social events to celebrate important dates, such as the end of the school term and the arrival of refugees long 
detained on Nauru; regular excursions, including three weekend-long trips to rural Victoria; and theatrical productions developed to feature refugees and their survival stories.

A research study involving focus groups with twenty-five refugees, as well interviews with volunteers and refugee support workers, indicated that the Network's activities have enabled some refugees on TPVs to develop a strong sense of belonging at the community level. ${ }^{40}$ Real friendships have emerged between refugees, as well as between refugees and Australian citizens. For instance, a small number of the men are in relationships with Australian women while others have found an "Australian Mum." These friendships have been crucial given that most refugees on TPVs are dislocated from their biological families and are denied the right to family reunion. For a refugee on a TPV from Syria, the Network itself provided a "family" for him:

The Fitzroy Learning Network has changed my life. Here I found my family, my friends, and my community; here I found my life .... I like to spend all my time at the Network because I feel very isolated in my flat. Here I talk to people, practice my English and ask them for help if I need something like using the Job Network or other services. Maybe I will never see my real family again but these people are here for me forever. ${ }^{41}$

Trust, a quality often difficult for refugees to regain, has been developed through such relationships. For example, having shared food and accommodation for several days on a Network camping holiday, refugees on TPVs - most of whom travelled to Australia on a leaky boat from Indonesia - found themselves able to participate in a yachting trip with the support of friends whom they trusted. Such trust is mainly at the local level, but is spreading because the relational networks in which refugees on TPVs have become embedded are spatially extensive. For instance, a recent weekend visit to the town of Daylesford saw locals billet the Network's refugees. As a result, refugees on TPVs in Melbourne now have friends in regional Victoria. This enhanced awareness of an alternative public discourse, one gradually gaining momentum as the thousands of Australians embarrassed by their government's TPV and mandatory detention regimes begin to speak out, has encouraged a sense of hope and alleviated some of the shame felt by refugees on TPVs.

In addition, the Network's activities have enabled refugees on TPVs to forge alliances with sympathetic individuals in positions of power, including members of parliament and policy makers, which are beginning to have important legal and political repercussions. This is illustrated by a friendship that developed between a retired Australian teacher and an Afghan refugee after they met at a Network social event. The refugee visited each weekend for help with his English language study and called frequently to ask advice on a whole range of everyday matters. In return, he brought the Australian food and did maintenance jobs around her house. This friendship soon extended to the Afghan's wife, child, and brother, who were detained on the island of Nauru as part of the Australian Government's "Pacific Solution" policy, when the Australian and her friends began sending letters and parcels. ${ }^{42}$ More importantly, the Australian acted as an important middle person between the refugee, lawyers, and political advisors as they together fought for nine women and fourteen children on Nauru to be reunited with their husbands who had been granted TPVs in Australia. As a result of this collective effort, the Afghan, his family and several other families separated by the Pacific Solution have now been reunited and are living as permanent residents in New Zealand.

In addition to developing social belonging at the community level, many refugees on TPVs have also established less dense and directly interpersonal ties between groups of people who share a cultural similarity or legal equivalence. This sense of belonging at the category level has been facilitated by several of the Network's activities. For instance, two theatrical productions developed to feature refugee survival stories brought together refugees from a range of backgrounds to work as a team and acknowledge the experiences they share as a group. A refugee who took part noted:

I always wanted to tell my story and speak with people but I was afraid. The play made me face my fears of communicating with the others and helped me out of my isolation .... We are all connected through our experiences despite our different backgrounds. $^{43}$

In addition, the Network has actively supported refugees on TPVs in establishing voluntary associations based on their shared cultural identifies or their legal status. For instance, organizations representing the Afghan and Iraqi communities have been established. These include a separate Hazara Association which allows Afghans from this persecuted tribe to have their own voice in Australia, as was impossible in Afghanistan. Not necessarily reflecting a strong sense of community amongst refugee groups, such associations have created space for recognition at the category level in order to enter into dialogue with policy makers and politicians. ${ }^{44}$ The formation of the Al Amel TPV Holders Association is a classic example. "Al Amel" means "hope" in Arabic, a title reflecting the shared desire to cross cultural, national, and linguistic boundaries to work towards a shared goal: the granting of permanent protection to all refugees on TPVs. In this role, Al Amel advocates for change in immigration law, liaises with other groups, and assists with health, employment, and legal issues. 
In addition to responding to the sense of urgency and anxiety that surrounds the real threat of deportation for temporary citizens, such associations based on either cultural or legal categories have provided a vehicle for reclaiming and respecting the cultural and political identities of refugees. The considerable advocacy work conducted by refugees on TPVs with the Network's encouragement has also achieved this end. Most advocacy has been at the local level and includes school talks, media interviews, participation in research that documents the harmful effects of the TPV regime, and speech-making at pro-refugee rallies. However, some refugees have also been involved in direct political lobbying at the state and federal levels. For instance, several of the Network's refugees stood alongside employers, regional and rural mayors, and refugee supporters to tell their stories and call for a review of the TPV regime during a delegation to the Federal Parliament in November 2003. Importantly, the campaign was called "Refugees say THANK YOU to Australia," emphasizing their appreciation that many individuals and communities had made them feel welcome in the face of extremely unwelcoming government policy.

Whether at the local, state, or federal level, such activism has attempted to subvert dominant discursive representations by raising awareness about the TPV regime and countering the rhetoric that suggests that refugees on TPVs are not valid candidates for permanent citizenship. Given that public discourses are not static and identities may be created or changed in public interaction, this challenge to their representation as "bad" refugees has brought a sense of belonging to a disparate group of refugees whom government policy has tried to render powerless. ${ }^{45}$ The findings in Melbourne thus support Korac's comparative research, which highlighted the importance of active agency in successful social integration for individual refugees. ${ }^{46}$

\section{Conclusion}

In this paper we have emphasized the importance of deconstructing conventional notions of integration and belonging to reveal a far more nuanced interpretation of the "social" than normally acknowledged by refugee resettlement policy and programs. A differentiation between relational networks, cultural or legal categories, and discursive publics has assisted in explaining the ambiguous and ambivalent resettlement experiences of refugees on TPVs in Australia. Findings from two qualitative research studies have offered evidence to suggest that the politics of belonging consist of sets of overlapping and interconnected processes that take place differently in various sub-sectors and spheres of receiving societies and have various outcomes. In this way, it has been possible for refugees on TPVs in
Australia to show strong signs of social integration and belonging in terms of relational networks and cultural or legal categories, as well as active resistance to negative representations at the public level, while at the same time feeling the material and psychological effects of the divisive public discourse that demonizes refugees on TPVs.

Social integration is clearly not a singular, stage-sequential process. There is consequently a need to reassess refugee policy and programs which tend to be based on such an assumption. We support Korac's call for strategies to be implemented that build the kind of relationships and networks which facilitate wider social belonging and integration. ${ }^{47} \mathrm{We}$ also agree that there needs to be greater acknowledgment of refugees as social actors, instead of policy objects or targets. This is particularly the case when the paper indicates that such a sense of belonging at the community and category levels is a crucial factor in developing the trust and empowerment necessary to challenge the negative representations of asylum seekers that currently dominate public discourse in Australia.

\section{Notes}

1. Craig Calhoun, "Nationalism, Political Community and the Representation of Society: Or, Why Feeling at Home is Not a Substitute for Public Place," European Journal of Social Theory 2, no. 2 (1999): 217-31.

2. See Canadian Council for Refugees, "Best Settlement Practices: Settlement Services for Refugees and Immigrants in Canada (Montreal: Canadian Council for Refugees, 1998); and John Berry, "Acculturation and Psychological Adaptation amongst Refugees," in Refugees - The Trauma of Exile: The Humanitarian Role of Red Cross and Red Crescent, ed. D. Miserz (Dorprecht: Martinus Nijhoff, 1988), 97-110.

3. See Robert Heipel, "Refugee Resettlement in a Canadian City: An Overview and Assessment," in Refugee Policy: Canada and the United States, ed. Howard Adelman (Toronto: York Lanes Press, 1991), 344-55; and Maja Korac, "Integration and How We Facilitate It: A Comparative Study of the Settlement Experiences of Refugees in Italy and the Netherlands," Sociology 37, no. 1 (2003): 51-68.

4. John Berry, Uichol Kim, and Pawel Boski, "Psychological Acculturation of Immigrants," in Cross-Cultural Adaptation: Current Approaches, ed. Y.K. Kim and W. Gudykunst (Newbury Park: Sage, 1988), 62-89.

5. Man Hau Liev, "Well-being and Cultural Maintenance," in Refugee Resettlement and Wellbeing, ed. M. Abbott (Auckland: Mental Health Association of New Zealand, 1989), 1-6.

6. Abdi Bihi, "Cultural Identity: Adaptation and Well Being of Somali Refugees in New Zealand," (M.A. Research Paper in Development Studies, Victoria University of Wellington, 1999).

7. Korac, 59-63.

8. Ibid., 56-62.

9. Calhoun, 1999, 219-20. 
10. Craig Calhoun, Social Theory and the Politics of Identity (Oxford: Blackwell, 1994), 20-21.

11. Calhoun, 1999, 219.

12. Stephen Castles, "Towards a Sociology of Forced Migration and Social Transformation," Sociology 37, no. 1 (2003): 13-34.

13. Calhoun 1999, 223.

14. Castles, 14-15.

15. Mary Crock and Ben Saul, Future Seekers: Refugees and the Law (Sydney: Federation Press, 2002).

16. See James Jupp, From White Australia to Woomera: The Story of Australian Immigration, (Cambridge: Cambridge University Press, 2002).

17. Katherine Betts, "Immigration Policy under the Howard Government," Australian Journal of Social Issues 38, no. 2 (2003): 169-92.

18. Department of Immigration and Multicultural and Indigenous Affairs, Fact Sheet 64: Temporary Protection Visas (Canberra: DIMIA, 2002). New developments in the run-up to the 2004 Federal election suggested that refuges holding TPVs would be able to apply for permanent residency through mainstream immigration processes. At the time of writing, it appeared most would not be able to meet the strict criteria guiding permanent residence decisions. It was also unclear whether this change in policy would automatically apply to those previously denied any right to permanent protection due to the "seven-day rule."

19. See Marcus Einfeld, "Is There a Role for Compassion in Refugee Policy," UNSW Law Journal 23, no. 3 (2000): 303-14; and Catholic Commission for Justice, Development and Peace, Forgotten People, Asylum in Australia, Occasional Paper No.10 (Melbourne: Catholic Commission for Justice, Development and Peace, 2001).

20. Peter Mares, Borderline, 2nd ed. (Sydney: University of New South Wales Press, 2002), 18.

21. See Refugee Council of Australia, Frequently Asked Questions, $<$ http://www.refugeecouncil.org.au/html/facts_and_stats/facts. htm l> (accessed on September 8, 2003).

22. Michelle Grattan, "Fighting to Let Refugees Stay," The Age, November 12, 2003, 15.

23. David Marr and Marian Wilkinson, Dark Victory (Crows Nest: Allen and Unwin, 2003), 176.

24. Katy Nebhan, "Identifications: Between Nationalistic 'Cells' and an Australian Muslim Ummah," Australian Journal of Social Issues 34, no. 4 (1999): 371-85.

25. Castles, 16.

26. John Howard, "Strength through Diversity" (Address at Multicultural Policy Announcement, Adelaide, October 16, 2001).

27. Cited in Marr and Wilkinson, 214.

28. Cited in Mares, 16.

29. This refers to claims made by the Australian Government suggesting that asylum seekers on a boat intercepted by the Australian Navy in October 2001 had begun to throw their children in the water to avoid their boat being escorted out of Australian waters. These claims were proved false only after the Liberal-National government was returned to power in the Federal election of November the same year.
30. Cited in Marr and Wilkinson, 189.

31. See Patricia Harris and Vicki Williams, "Social Inclusion, National Identity and the Moral Imagination," in The Drawing Board: An Australian Review of Public Affairs 3, no. 3 (2003): 205-22.

32. See Korac, 62.

33. See Brotherhood of St Lawrence, "Seeking Asylum: Living with Fear, Uncertainty and Exclusion," Changing Pressures Bulletin 11 (November 2002): 1-8; Mares; Greg Marston, Temporary Protection, Permanent Uncertainty: The Experiences of Refugees Living on Temporary Protection Visas (Melbourne: Centre for Applied Social Research, RMIT University, 2003); Fethi Mansouri and Melek Bagdas, Politics of Social Exclusion: Refugees on Temporary Protection Visa in Victoria (Melbourne: Deakin University, 2002).

34. This table was adapted from Brotherhood of St Lawrence, 3.

35. Korac, 54.

36. Marston.

37. Louise Humpage with the Fitzroy Learning Network, Opening Doors to Our Community: A Framework for Engaging Victoria's Newest Residents - Refugees, Temporary Protection Visa Holders and Asylum Seekers (Melbourne: Centre for Applied Social Research, RMIT University, 2004).

38. Grattan, 15.

39. See John Clarke, "A World of Difference? Globalization and the Study of Social Policy," in Rethinking Social Policy, ed. G. Lewis, S. Gewirtz ,and J. Clarke (London: Sage Publications, 2000); Richard Sennett, Respect: The Formation of Character in an Age of Inequality (London: Allen Lane, 2003).

40. Some of these refugees also participated in the earlier research conducted by Greg Marston.

41. Fitzroy Learning Network, Opening Doors to Our Community: Annual Report 2002 (Melbourne, 2002), 18.

42. The "Pacific Solution" has involved the Australian Government detaining asylum seekers from intercepted boats on the island-state of Nauru and Papua New Guinea's Manus Island in an effort to deny them access to the Australian legal system.

43. Ibid., 12.

44. See Lynnette Kelly, "Bosnian Refugees in Britain: Questioning Community," Sociology 37, no. 1 (2003): 35-49.

45. Calhoun, 1999, 223.

46. Korac, 62.

47. Korac, 51-54.

Louise Humpage is a Post-Doctoral Research Fellow in the Centre for Applied Social Research at RMIT University, Melbourne. She is currently researching in the areas of refugees, indigenous peoples, and social policy.

Greg Marston is a Lecturer in the School of Social Work and Applied Human Sciences, University of Queensland. Greg is undertaking research in the areas of income support, employment services, and refugee policy. 